\title{
MITOS JENIS KELAMIN BAYI PADA IBU HAMIL DI MASYARAKAT MINANGKABAU
}

\author{
Silvia Devi \\ Balai Pelestarian Nilai Budaya Padang \\ Jl. Raya Belimbing No 16 A, Kuranji, Padang \\ silvia160681@gmail.com
}

\begin{abstract}
Abstrak
Peristiwa kehamilan pada setiap perempuan berbeda pengalamannya. Bahkan dari satu ibu saja ketika hamil anak pertama akan mengalami perbedaan dengan kehamilan anak selanjutnya. Oleh karena itu banyak mitos tanda-tanda yang ditampilkan ibu hamil dan memiliki mitos sendiri bagi masyarakat Minangkabau dalam menebak jenis kelamin bayi.Tujuan penelitian ini adalah mengetahui mitos tandatanda dan usaha yang dilakukan oleh seorang ibu hamil guna mendapatkan anak dengan jenis kelamin tertentu.Penelitian ini menggunakan metode deskriptif dengan pendekatan kualitatif. Pengumpulan data dengan observasi dan wawancara dengan informan yakni tiga orang tukang urut dan lima orang perempuanyang pernah melakukan upaya mendapatkan anak berjenis kelamin tertentu. Hasil penelitian ini diketahui bahwa sebagian dari mitos tanda-tanda dan usaha yang dilakukan untuk mendapatkan anak dengan jenis kelamin tertentu diyakini kebenarannya. Namun sebagian lain tidak membuahkan hasil. Akan tetapi, hal ini tidak menyurutkan usaha dari seorang perempuan untuk mendapatkan keinginan anak dengan jenis kelamin tertentu yang didambakannya.
\end{abstract}

Kata Kunci: ibu hamil,mitos, jenis kelamin

\section{A. PENDAHULUAN}

Masyarakat minangkabau dikenal sebagai masyarakat yang memilikifilosofi adat basandi syarak syarak basandi kitabullah.Filosofi ini sangat kental bagi masyarakat minangkabau dalam melewati setiap tahapan kehidupannya di setiap generasi.Berbagai macam upacara dilaksanakan dalam kehidupannya dimulai dari tahapan kelahiran, tumbuh besar dari masa anak-anak, remaja dan dewasa. Ketika dewasa akan memasuki tahapan perkawinan, kemudian mengandung dan melahirkan, setelah itu kematian. Pada setiap tahap pelaksanaanmemiliki tata cara dan keyakinan sendiri demi mencapai kebahagiaan dan kesempurnaan hidup. Dahulu dimana agama Islam belum dikenal, maka banyak dilaksanakan berbagai upacara sesuai dengan keyakinan pada masa itu, yakni adanya keyakinan kepada roh atau animism maupun keyakinan terhadap bendabenda atau dinamisme.Namun, setelah masuknya Islam dalam masyarakat Minangkabau, kegiatan dalam lingkaran kehidupan tersebut tetap dilakukan berbagai upacara tetapi sudah banyak perubahan seperti yang terlihat dalam penggunaan dupa atau kemenyan sudah dikurangi atau bahkan ada yang sudah meninggalkannya.

Filosofi yang berdasar pada agama Islam dan adat seyogyanya tidak bisa dibiarkan berlawanan dalam penerapannya di dalam kehidupan masyarakat. Setiap kegiatan yang dilaksanakan harus sejalan dengan ajaran Allah SWT dengan berpedoman pada AlQur'an dan sunah Rasul. Oleh karena itu adat yang diajarkan oleh nenek moyang masyarakat Minangkabau 
tidak dibenarkan dilaksanakan sekehendak hati.Semua harus dilalui dengan berbagai pertimbangan baik moral (agama) maupun sosial.

Suatu tindakan yang meragukan atau mengacaukan keyakinan kita terhadap Tuhan Yang Maha Esa sangat dilarang dalam agama Islam yang merupakan agama yang dianut oleh suku Minangkabau.Oleh karena itu jika kita sebagai umat Islam bertindak atau berperilaku justru melawan terhadap ajaranNya, itu bisa dikatakan tidak lagi sebagai suku Minangkabau.Ini adalah kesimpulan ideal penulis jika semua tindak tanduk masyarakat Minangkabau dilakukan sesuai dengan ajaran agama Islam.

Meskipun ajaran agama Islam sangat melarang mempercayai suatu hal diluar keyakinan yang telah diajarkan, tetapi banyak juga masyarakat yang melanggar.Hal ini tidak bisa dihindari dikarenakan perkembangan pola pikir masyarakat yang selalu berubah.Lalu apa arti dari mitos tanda-tanda dan usaha yang dilakukan untuk mendapatkan bayi dengan jenis kelamin tertentu? Apakah itu telah melanggar syariatNya?Apakah itu mitos yang hanya merupakan cerita bohong atau bisa dibuktikan kebenarannya oleh masyarakat? Untuk menemukan jawabannya, maka akan diterangkan terlebih dahulu apa mitos itu?

Mitos atau dikenal juga dengan kata lain mitologi yang merupakan bagian dari folklore.Folklore yang berasal dari dua kata folk yang artinya rakyat dan lore artinya cerita.Mitos merupakan gambaran atau refleksi dari kehidupan masyarakat suatu daerah yang bisa berbentuk mitos, legenda, dongeng ataupun permainan rakyat.Keberadaan folklore selalu muncul lalu berkembang dan bisa mengalami perubahan dari suatu kelompok masyarakat. Menurut Kamus Umum Besar Bahasa Indonesia (1997:660) pengertianmitos adalah suatu cerita bangsa tentang dewa dan pahlawan zaman dahulu, yang mengandung penafsiran tentang asal usul semesta alam, manusia dan bangsa itu sendiri yang mengandung arti mendalam yang diungkapkan dengan cara gaib.Tetapi dari karangan berbagai peneliti dikatakan bahwa mitos bukanlah hasil takhyul atau pemikiran keliru yang belum matang dari orang-orang yang tidak mampu berfikir jernih serta logis serta masih terbelenggu dalam kegelapan fantasi yang aneh-aneh sebagaimana yang dipikirkan para ilmuwan zaman Pencerahan abad ke -17 di Eropa (Claude Levi-Strauss, 1997: $31)$.

Menurut Sidarta Pujiraharjo (1998:48) mitos mempunyai kedudukan yang penting dalam ystem budaya masyarakat, karena mitos berisi tentang norma kehidupan dalam ystem budaya masyarakatnya. Mitos ini juga memunculkan suatu penilaian yang berlaku dalam ystem sosial masyarakat.Jika kita hubungkan perkembangan mitos dengan filosofi kehidupan masyarakat Minangkabau, maka secara nyata bisa dikatakan mengingkari filosofi hidup berlandaskan agama Islam.Karena meyakini sesuatu di luar ajaran agama Islam tentu sudah bisa dikatakan syirik.Syirik adalah perbuatan yang dilarang dan tidak diampuni oleh Allah SWT.

Lalu bagaimana kita memahami mitos yang berkembang mengenai melalui tanda-tanda yang ditampilkan oleh ibu hamil terkait jenis kelamin si bayi dalam kandungan.Mitos ini berbeda dengan mitos yang secara umum dikenal, seperti mitos asal usul daerah, mitos manusia, binatang, atau dewa, yang biasanya ditokohkan dengan orang-orang yang suci.Mitos terhadap tandatanda jenis kelamin bayi pada ibu hamil sebenarnya tidak hanya berkembang di masyarakat 
Minangkabau tetapi juga berkembang di luar Minangkabau.Banyak tanda-tanda yang dianggap oleh masyarakat yang dapat dilihat dari bentuk dan usaha si ibu hamil dalam mencapai keinginannya.Tanda-tanda setiap orang berbeda-beda. Namun begitu, tanda-tanda yang diperlihatkan oleh ibu hamil dan usaha yang dilakukan oleh ibu hamil demi mencapai keinginannya akan jenis kelamin tertentu bisa dianggap mitos dikarenakan diragukan kebenarannya. Oleh karena itu, yang menjadi pokok permasalahan dalam penulisan ini adalah:

1. Apa saja mitos tanda-tanda yang diperlihatkan pada ibu hamil yang terkait dengan jenis kelamin bayi yang dikandungnya?

2. Usahaapa saja yang dilakukan guna mendapatkan keinginannya terhadap anak berjenis kelamin tertentu?

Dari uraian latar belakang dan pokok permasalahan di atas, maka tujuan penulisan ini adalah :

1. Apa saja mitos tanda-tanda yang diperlihatkan pada ibu hamil yang terkait dengan jenis kelamin bayi yang dikandungnya?

2. Usahaapa saja yang dilakukan guna mendapatkan keinginannya terhadap anak berjenis kelamin tertentu?

Penelitian mengenai mitos-mitos yang berkembang yang terkait pada ibu hamil, baik itu pantang dan larang yang berkembang di tengah masyarakat telah banyak dilakukan.Mitos-mitos terkait kepercayaan yang berkaitan erat dengan latar belakang sosial budaya masyarakat tersebut. Penelitian itu antara lain yang dilakukan oleh Ida Utari dengan judul penelitian Study of Developing The Myths Of Pregnancy Bidan Praktek Swasta Zubaidah. ${ }^{1}$ Dari hasil penelitian ini diketahui bahwa masyarakat di Desa Sumber Simo Boyolali mengenai mitos kehamilan berkaitan dengan perubahan anatomi dan fisiologi ibu hamil, makanan yang dilarang dan dianjurkan dan berkaitan dengan tingkah laku/psikis ibu hamil masih sangat lekat dan dipercaya oleh ibuibu hamil di desa Sumber Sambi Boyolali. Adapun Mitos kehamilan berkaitan dengan makanan yang dilarang dan untuk ibu hamil.Larangan makan meliputi : makan nanas $(68,1 \%)$, dagingkambing (60\%), makan ikan laut (36\%), makan buah stroberi $(72,7 \%)$, makan yang pedas-pedas $(68,1 \%)$, jika ngidam harus dituruti. Adapun anjuran bagi ibu hamil meliputi : banyak minum air kelapa agar membantu mempercepat proses kelahiran 981,8 dan minum minyak kelapa (satu sendok makan perhari) menjelang kelahiran $(81,8 \%)$. Ibu hamil masih banyak yang percaya dengan mitos berkaitan dengan tingkah laku/psikis ibu hamil berupa :dilarang menutup segala lubang $(90,8 \%)$, dilarang lewat dibelakang ibu hamil yang sedang duduk $(81.8 \%)$, dilarang makan dengan piring yang besar $(63,6 \%)$, dilarang mengangkat jemuran dan melakukan gerakan yang berat $(86,3 \%)$. Sedangkan mitos yang berkaitan dengan jenis kelamin bayi dalam kandungan ditandai dengan mitos-mitos yang dipercayai, dengan hasil seperti berikut : detak jantung bayi rendah $72.7 \%$, kandungan berat kebawah $60 \%$ dan putting payudara berwarna lebih gelap $63,6 \%$. Meskipun mitos-mitos yang berkembang dianggap tidak

${ }^{1}$ https://publikasiilmiah.ums.ac.id/bitstream/handle/11617/5178/7.Ida\%20Utari.pdf?sequence=1 Akses 27 Januari 2016. 
benar sama sekali, tetapi hal ini tidak mempengaruhi tingkat kepercayaan ibu hamil di desa ini untuk percaya.

Kajian mengenaimitos dimasa kehamilan dan kelahiran yang dilakukan di Minangkabau pernah dilakukan oleh Yunis di tahun 2010. M. Yunis menguraikannya mitos dari sudut pandang linguistic yakni Tindak Tutur, Semiotik, e 135, dan Filsafat Kehendak. Beberapa mitos yakni urang manganduang nda buliah malala, nda buliah lalu dibelakang urang manganduang, urang manganduang nda buliah duduak di pintu. Mitos-mitos ini sangat erat kaitannya dengan menciptakan kebaikan bagi perempuan hamil dan juga bagi semua orang. Mengapa tindak tutur ini dikenakan kepada orang hamil, dikarenakan anak dalam kandungan adalah cikal bakal manusia yang akan lahir di dunia dengan pengharapan memiliki sikap yang baik di dunia. Masa kehamilan adalah masa pertama manusia dibentuk dan harus ditanamkan segala nilai-nilai baik.Agar tujuan penananaman nilai tercapai maka terbentuklah mitos-mitos yang sangat berguna dalam kehidupan masyarakat Minangkabau.

Terkait dengan kehamilan dan kelahiran adalah adanya profesi dukun bayi. Kajian mengenai dukun bayi telah banyak dilakukan, antara lain kajian yang dilakukan oleh Zusneli Zubir dan Silvia Devi tahun 2015 yang berjudul Dukun Bayi Nagari Koto Anau: Potret Pengobatan Tradisional 1979-2012. Dalam kajian itu penulis menguraikan bagaimana masyarakat Koto Anau yang bukan merupakan masyarakat tertinggal dan merupakan masyarakat yang memiliki tingkat pendidikan yang baik ditengah maraknya pengobatan modern tetapi masih menggunakan pengobatan tradisional khususnya kepada dukun bayi.Penulis juga menggambarkan bagaimana program bidan desa yang dianggap memarjinalkan profesi dukun bayi.

Tetapi penelitian khusus tentang mitos tanda-tanda jenis kelamin pada ibu hamil dan usaha untuk mendapatkan bayi dengan jenis kelamin tertentudi tengah masyarakat Minangkabau belum pernah dilakukan.Oleh karena masyarakatMinangkabau merupakan masyarakat yang memiliki filosofi adat basandi syarak syarak basandi kitabullah. Sedangkan mitos tanda-tanda dan usaha yang dilakukan terkadang sangat sulit untuk masuk akal, tetapi mitos tersebut tetap berkembang di tengah masyarakat dan masih banyak masyarakat yang mempercayai hal tersebut.

\section{B. METODOLOGI}

Adapun lokasi penelitian ini dilakukan di Kecamatan Ampek Angkek Kabupaten Agam.Alasan utama dari pemilihan lokasi ini adalah masih banyaknya masyarakat yang mempercayai mitos dari tanda-tanda yang diperlihatkan oleh ibu hamil dan masih tingginya usaha yang dilakukan oleh ibu hamil tersebut agar mendapatkan anak dengan jenis kelamin tertentu melalui tukang urut. ${ }^{2}$ Padahal petugas kesehatan modernbaik itu Bidan, dokter di

\footnotetext{
${ }^{2}$ Istilah tukang urut digunakan oleh penulis karena informasi yang didapat menganggap dirinya bukan seorang dukun.Mereka lebih menyukai dikenal sebagai tukang urut walaupun pekerjaan mereka dengan keahlian yang didapat dari turun menurun dan tidak bersifat komersil.Sebenarnya tukang urut dan dukun tidak berbeda. Adapun pengertian dukun biasanya seorang wanita sudah berumur \pm 40 tahun ke atas, pekerjaan ini turun temurun dalam keluarga atau karena ia merasa mendapat panggilan tugas ini.
} 
Puskesmas dan dokter di Rumah Sakit tidak terlalu sulit untuk ditemui karena jaraknya juga tidak terlalu jauh.Umumnya mereka juga berkonsultasi kepada petugas kesehatan dalam tiap bulan kehamilannya bahkan sampai kelahiran bayi mereka. Tetapi terhadap tanda-tanda dan usaha untuk mencapai keinginan mereka dalam mendapatkan anak dengan jenis kelamin tertentu hanya mereka percayai dan lakukan melalui tukang urut.Bagi mereka pengetahuan tukangurut dalam menentukan jenis kelamin bayi lebih bisa dipercaya dibandingkan dengan teknologi USG di rumah sakit.Dengan demikian peneliti berasumsi bahwa masyarakat Ampek Angkek masih banyak yang percaya akan mitos tanda-tanda dan usaha mendapatkan anak dengan jenis kelamin tertentu melalui tukang urut.

Penelitian ini menggunakan pendekatan kualitatif dengan metode studi kasus deskriptif.Metode penelitian ilmu-ilmu sosial secara umum adalah mengumpulkan dan menganalisa data berupa kata-kata (lisan maupun tulisan) dan perbuatan manusia bukan menganalisa angka-angka (Afrizal, 2008:14). Metode deskriptif dilakukan dalam rangka mendapatkan gambaran secara menyeluruh dalam memahami mitos dari tanda-tanda ibu hamil yang diuraikan pula bagaimana usaha yang dilakukan oleh sekelompok masyarakat tersebut.Sedangkan metode studi kasus digunakan dalam hal penelitian ini seperti yang didefinisikan oleh Yin (2011:18) bahwa studi kasus adalah suatu inkuiri empiris yang menyelidiki fenomena di dalam konteks kehidupan nyata, bilama batas-batas antara fenomena dan konteks tak tampak dengan tegas, dan di mana multisumber bukti dimanfaatkan.

Teknik pengumpulan data yang dilakukan adalah dengan cara observasi dan wawancara mendalam. Observasi adalah salah satu cara yang dilakukan oleh peneliti untuk dapat mengamati secara langsung situasi dan kondisi lingkungan fisik dan berbagai perilaku yang ditunjukkan dalam interaksi masyarakat di lokasi penelitian dalam aktivitasnya sehari-hari. Observasi dilakukan di rumah tukang urut yang sedang melakukan pengobatan.Hal ini dilakukan agar bisa mendapatkan data sesuai dengan realitas masyarakat yang ada.Observasi diikuti dengan kegiatan pencatatan data lapangan.

Teknik wawancara yakni pengumpulan data dengan mengajukan pertanyaan pada informan yang memiliki keahlian tentang pokok wawancara berdasarkan pedoman wawancara guna membantu peneliti mendapatkan informasi sesuai dengan tujuan penelitian. Wawancara mendalam dilakukan karena tidak semua data didapat dari observasi yang sudah dilakukan.Perlu dilakukan wawancara mendalam untuk mendapatkan informasi secara lebih terinci terkait dengan keperluan data lapangan.Wawancara mendalam dilakukan kepada tukang urut dan beberapa ibu yang pernah melakukan berbagai usaha mendapatkan anak dengan jenis kelamin tertentu baik yang berhasil ataupun tidak berhasil.

Teknik lain yang penting dalam penelitian ini adalah studi kepustakaan, yakni teknis pengumpulan data dengan mengumpulkan berbagai ystemne baik itu buku, majalah, ystemn dan Koran yang berisikan konsep-konsep dan teori-teori yang terkait dengan tujuan penelitan. Studi kepustakaan dilakukan dimulai sejak awal penulisan sampai analisa data.

Informan adalah orang-orang yang berkaitan langsung dengan permasalahan dan tujuan penelitian.Pemilihan informan dilakukan dengan teknik snowball yakni dengan mencari tahu 
informan pangkal (informan kunci) kemudian terus berkembang ke informan yang lainnya yang dianggap memiliki pengetahuan tentang penelitian ini.Alasan teknik ini digunakan karena peneliti tidak mengetahui siapa saja yang pernah melakukan pengobatan untuk mendapatkan anak dengan jenis kelamin tertentu.Oleh Singarimbun (1986:67) Informan yang dipilih memiliki dua kategori, yakni:

1. Informan kunci (key informan), yakni orang-orang yang dianggap sangat paham mengenai mitos tanda-tanda yang tampak pada ibu hamil dan juga usaha yang dilakukan agar bisa mendapatkan anak dengan jenis kelamin tertentu. Informan kunci dalam penelitian ini adalah tukang urut, ibu yang sedang hamil, dan beberapa ibu yang pernah melakukan usaha mendapatkan anak dengan jenis kelamin tertentu baik yang berhasil maupun yang tidak berhasil.

2. Informan biasa adalah orang-orang yang dapat memberikan data terbuka yang diperlukan sesuai dengan tujuan dalam penelitian. Dalam hal ini yang menjadi informan biasa adalah siapa pun yang mengetahui mengenai tanda-tanda dan usaha yang dilakukan oleh ibu hamil dikaitkan dengan jenis kelamin anak yang dikandungnya.

Analisa data menurut Patton (1980: 268) adalah mengurutkan data, mengorganisasikannya ke dalam suatu pola, kategori dan satuan uraian dasar. Data-data hasil observasi dan wawancara selanjutnya dianalisa secara kualitatif, sedangkan data yang didapat berupa yste-tabel atau angka-angka akan dianalisa secara kuantitatif. Analisa data dilakukan secara berkelanjutan yang dimulai semenjak data pertama didapatkan. Analisis data dilakukan untuk keperluan merumuskan masalah dan yste penelitian. Ketika penelitian berlangsung, data dianalisis untuk mempertajam yste dan pengecekan keabsahan data.Di akhir penelitian, analisis data dilakukan untuk membuat kesimpulan akhir.

\section{B. PEMBAHASAN}

\section{Minangkabau dan Adat Basandi Syara' Syara' Basandi Kitabullah}

Masyarakat Minangkabau memiliki tradisi dalam berbahasa yakni dengan tidak mengungkapkan semua hal dengan cara ujaran langsung. Masyarakatnya mengenal istilah kieh jo kato. Arti kieh adalah bahasa kiasan yang mengungkapkan sesuatu dengan sindiran. Sedangkan kato adalah bahasa yang diungkapkan dengan bahasa yang sebenarnya. Jadi baik pantangan atau anjuran biasanya disampaikan dengan kieh jo kato sesuai dengan konteksnya. Contoh Adapun salah satu contohnya adalah "sayang ka anak makonyo dilacuik", sayang dengan anak makanya dipukul. Maksud dari tuturan ini adalah bahwa bukan berarti bahwa untuk memberikan kasih sayang kepada anak, maka anak selalu menerima pukulan dari orangtuanya. Semua ini bermakna bahwa anak jangan selalu dimanjakan karena nantinya justru akan sulit bagi sang anak untuk menghadapi suatu persoalan dalam perjalanan kehidupannya. Anak yang manja selalu mendapatkan segala apa yang dia inginkan. Dia tak terbiasa untuk menggunakan pikiran dan hatinya dalam mempertimbangkan keinginannya. Yang dia tahu semua permintaan akan terkabulkan. Itulah makanya, anak dibekali dengan segala pengetahuan, kesabaran dan kemauan 
untuk berusaha mencapai apa yang dia inginkan atas usahanya dia sendiri. Jika sang anak mulai kelewatan manjanya bahkan melanggar suatu norma baik agama ataupun adat maka selayaknya anak mendapatkan hukuman. Di lacuik tersebut artinya pukulan sebagai suatu hukuman bagi dirinya. Biasanya dengan adanya hukuman, maka sang anak akan malu atau takut sehingga ia tidak akan mengulangnya kembali. Tujuan ini tidak hanya bagi sang anak yang terkena lacuak an tadi saja. Tetapi berlaku untuk semua anak dimana pun berada.

Begitu juga dengan mitos yang lahir dari bahasa atau tuturan. Hal ini sebagaimana yang diungkapkan oleh Yunis (2010:14) bahwa tuturan merupakan penjelmaan dari sikap yang akan dilakukan, sikap yang diharapkan sesuai dengan maksud tuturan.Contoh bahasa yang diungkapkan sebagai mitos pada ibu hamil yakni ibu hamil dan suaminya pantang membunuh binatang. Maksud dari mitos ini adalah agar ibu hamil membiasakan diri untuk menumbuhkan sikap kasih sayang baik pada binatanataupun dengan mahluk Tuhan yang lainnya. Mitos orang hamil yang dilarang untuk keluar malam nanti diganggu mahluk gaib juga memiliki maksud harapan agar sang ibu hamil tidak suka keluyuran. Kalau terjadi sesuatu akan sangat membahayakan baik terhadap ibu ataupun bayi yang dikandungnya. Seorang ibu hamil harus bisa menjaga kesehatannya dengan banyak beristirahat, bukannya pergi keluyuran apalagi malammalam.Banyak lagi mitos yang nyata berkembang di tengah masyarakat ternyata memiliki manfaat yang baik bagi ketertiban dan kedamaian di tengah masyarakat.Keberadaan mitos ternyata lebih ditaati oleh masyarakat.Hal ini dikarenakan kuatnya nenek moyang menanamkan nilai-nilai tersebut kepada anak keturunannya.Adapun mitos-mitos yang berkebaang agar tidak terjebak dengan tindakan yang melanggar ajaran agama Islam, maka harus bisa memaknainya dengan arif dan bijaksana.Sehingga banyak mitos yang berkembang tidak semuanya memiliki kebenaran.Namun, hal ini bukan pula dapat disimpulkan bahwa semua mitos yang berkembang benar adanya.Semua tergantung pada keyakinan diri masing-masing.

Begitu kuatnya keyakinan masyarakat akan keberadaan mitos yang memilki daya guna, hal ini terkait dari fungsi mitos itu sendiri di tengah masyarakat. Adapun fungsi mitos menurut Van Peursen (2013) yakni : menyadarkan manusia bahwa ada kekuatan-kekuatan ajaib, memberi jaminan pada masa kini, memberi pengetahuan tentang dunia.

Mitos diyakini berisi anjuran atau larangan yang tujuan salah satunya adalah menjaga manusia dalam membentuk kesimbangan dengan alam sekitar.Semua yang diciptakan Tuhan di dunia ini adalah berguna dalam membentuk kesimbangan.Seperti bumi dan langit diciptakan secara seimbang oleh Tuhan. Di bumi terdapat api dan air, udara dan tanah. Hewan dan tumbuhan.Begitu juga dengan jenis kelamin, ada jantan ada betina, ada jenis kelamin laki-lakilaki maka ada jenis kelamin perempuan. Keyakinan akan pentingnya suatu hal itu berimbang, menyebabkan manusia berusaha mendapatkan sesuatu yang seimbang tersebut.

Sebenarnya kepercayaan kepada mitos tidak hanya dimiliki oleh masyarakat Minagkabau saja.Tetapi juga dimiliki oleh seluruh masyarakat di seluruh penjuru dunia. Mitos lahir sebagai suatu bahasa atau tuturan yang diungkapkan akan suatu peristiwa, kemudian diungkapkan secara berulang-ulang dansuatu hari terbukti. Jadilah itu suatu kebenaran bagi suatu masyarakat yang meskipun dikatakan mitos tetapi tetap dianggap benar adanya oleh sebagian masyarakat yang meyakininya. 
Sejarah Minangkabau sangat lekat dengan mitos.Hal ini dapat dilihat dari adanya Tambo Minangkabau yang tetap masih dipercayai jika seseorang mencari tahu asal-usul Minangkabau.Tambo dikatakan oleh Mansyur hanya beirisi 2\% kebenaran dan selebihnya yakni 98\% berisi kebohongan (1970:37).Akan tetapi, tetap saja masyarakat Minangkabau menjadikan mitos itu sebagai dasar manakala dipertanyakan bagaimana sejarah dari Minangkabau itu sendiri. Seperti pertanyaan Sajak bilo Minangkabau ko ado? Sajak gunuang marapi sagadang talua ituak.

Mitos yang berkembang di tengah masyarakat Minangkabau sama halnya dengan yang ada di masyarakat lainnya yang berisi larangan atau anjuran yang diharapkan dapat melahirkan suatu keteraturan dalam menjalankan aktivitas kehidupan. Bahkan Yunis (2010:5) mengatakan bahwa mitos dipandang oleh masyarakat Minangkabau lebih bernilai guna.Hal ini terlihat dalam fakta di lapangan bahwa mitos lebih ditakuti oleh masyarakat sebagai penghukum atas segala tindakan yang salah di dalam menggauli kehidupan.

Mitos tak memihak kepada suatu individu dikarenakan strata ekonomi tertentu, tetapi bisa kepada seluruh pihak apakah orang miskin, orang kaya, orang bodoh bahkan bukan tidak mungkin orang yang memiliki tingkatan pendidikan yang tinggi. Hal ini dikarenakan mitos terbentuk dari hasil berfikir manusia akan sesuatu hal yang terjadi dalam kehidupannya. Lalu apa yang terjadi tersebut selalu diceritakan berulang-ulang dan suatu waktu terbukti. Oleh karena lama kelamaan terbukti kebenarannya maka hal tersebut dianggaplah nyata.Itulah mengapa mitos tersebut dianggap oleh masyarakat tidak semuanya bohong.Sekali lagi ditekankan bahwa semua tergantung kepada sikap seseorang dalam meyakini kebenaran suatu mitos itu sendiri.

\section{Arti kehadiran anak berjenis kelamin Laki-laki dan Perempuan di masyarakat Minangkabau}

Kehadiran anak laki-laki dan anak perempuan dalam suatu keluarga khususnya di masyarakat Minangkabau memegang arti penting. ${ }^{3}$ Tak lengkap rasanya suatu keluarga jika tidak memiliki anak.Salah satu tujuan keluarga adalah untuk mendapatkan keturunan.Atau jika satu keluarga hanya memiliki anak perempuan saja atau anak laki-laki saja juga dianggap tidak lengkap.

Masyarakat Minangkabau memiliki system garis keturunan ditarik dari garis ibu dan dikenal dengan istilah matrilineal. ${ }^{4}$ Oleh karena itu kehadiran anak jenis kelamin perempuan sangat didambakan dikarenakan akan meneruskan garis keturunan. Ketidakhadiran anak

\footnotetext{
${ }^{3}$ Lihat lebih jauh Ernatip dan Silvia Devi, 2014.Kedudukan dan Peran Bundo Kanduang dalam Sistem Kekerabatan Matrilineal di Minangkabau.Padang : BPNB Padang. Lihat juga Boestami dkk, 1992.Kedudukan dan Peranan Wanita dalam Kebudayaan Suku Bangsa Minangkabau.Padang: Penerbit Esa Padang. Lihat juga Nizar, Hayati, 2004.Bundo Kanduang dalam Kajian Islam dan Budaya.Padang : Pusat Pengkajian Islam dan Minangkabau Sumatera Barat.

${ }^{4}$ Garis keturunan ditarik garis ibu dikenal dengan istilah matrilineal, ini dianut oleh suku Minangkabau dan beberapa suku di Jawa.Garis keturunan ditarik dari garis laki-laki dikenal dengan istilah patrilineal salah satu contohnya adalah suku Batak Toba.Garis keturunan yang menarik garis dari pihak laki-laki dan pihak perempuan dikenal dengan istilah parental.Umumnya yang menganut system garis parental adalah suku Jawa.(Koentjaraningrat, 1998).
} 
perempuan dalam sebuah keluarga Minangkabau sangat berpengaruh seperti yang diungkapkan oleh Refisrul (2011) tidak hanya terkait dengan pelanjut garis keturunan, tetapi juga kurang lengkapnya kehidupan rumah gadang karena anak perempuan dianggap sumarak rumah gadang, kesulitan dalam pelaksanaan pekerjaan rumah tangga karena lazimnya dilakukan oleh kaum perempuan, terkait aktivitas sosial kemasyarakatan yang terlibat dalam baralek di setiap upacara adat, dan keresahan dalam menjalani masa tua. Oleh karena itu, biasanya sebuah keluarga kalau belum mempunyai keturunan anak perempuan, maka usaha untuk mendapatkan anak perempuan sangat gigih dilakukan. Jika tidak dilakukan maka akan punah sebuah garis keturunan. Dalam kasus ini dialami oleh Leni (45tahun) dan Via (34tahun). Leni memiliki 1 saudara laki-laki. Orangtuanya (dari garis ibu) pun hanya memiliki saudara laki-slaki satu orang dan tidak memiliki saudara perempuan. Jika Leni tidak memiliki anak perempuan maka akan punah dari garis keturunan Leni. Oleh karena itu Leni sangat berusaha untuk mencari jalan bagaimana mendapatkan anak berjenis kelamin perempuan setelah sebelumnya ia memiliki tiga orang anak laki-laki.

Begitu juga halnya dengan kasus Via (34 tahun). Via hanya memiliki tiga saudara lakilaki. Ditarik dari garis orangtua (dari garis ibu), maka sang ibu memiliki satu saudara perempuan dan empat saudara laki-laki. Satu orang saudara perempuan ibunya memiliki empat orang anak perempuan dan dua orang anak laki-laki.Dari empat anak perempuan tersebut tiga diantaranya memiliki anak perempuan lebih dari satu. Oleh karena itu dari garis keturunan saudara ibu Via tidak punah karena berkembang. Tetapi yang dikhawatirkan Via adalah dari garis keturunan ibunya yang hanya memiliki anak perempuan dari seorang diri Via. Oleh karena itu Via berusaha untuk mendapatkan anak perempuan agar keturunan Via tidak punah. Namun, kenyataan memperlihatkan bahwa usaha yang telah ia lalui dalam mencapai keinginan memiliki anak perempuan masih gagal. Tetapi ia masih terus berusaha semaksimal mungkin agar bisa mendapatkan keturunan anak perempuan walau hanya satu orang agar tidak punah.

Berbeda halnya dengan kasus Ida (51 tahun). Ida telah memiliki anak laki-laki sebanyak lima orang. Dari garis keturunan sang ibu, ia memiliki tiga saudara perempuan dan dua saudara laki-laki. Dari tiga saudara perempuannya memiliki anak berjenis kelamin perempuan, maka dia tidak terlalu khawatir karena tidak akan punah dari garis keturunan sang ibu. Tetapi dari garis keturunan Ida sudah punah dikarenakan ia tidak memiliki anak perempuan. Sebelumnya Ida telah berusaha sekuat mungkin untuk mendapatkan anak perempuan dengan menjalankan apa saja kata orang-orang yang dianggap bisa untuk mendapatkan anak perempuan. Tetapi nyatanya semua gagal, dan Ida menganggap dirinya memang sudah tidak ditakdirkan untuk memiliki anak perempuan.

Begitu juga dengan kasus Metra (30 tahun) yang memiliki anak laki-laki dua orang. Dari garis keturunan sang ibu ia memiliki satu orang saudara laki-laki. Sementara dari garis keturunan orangtua dari ibu memiliki delapan saudara perempuan dan dua orang saudara lakilaki. Dari delapan saudara perempuan sang ibu semuanya memiliki minimal satu orang anak perempuan. Itu artinya dari keluarga ibu garis keturunannya tidak punah. Sedangkan dari garis ibunya, jika ia tidak memiliki anak perempuan maka akan punah. Metra sudah berusaha untuk 
mendapatkan anak perempuan tetapi belum berhasil. Karena usianya masih muda, ia akan terus berusaha untuk mendapatkan anak perempuan.

Sedangkan kasus Susi (30 tahun) berbeda dengan kasus empat perempuan lainnya dalam penelitian ini.Susi pada awalnya memang belum memiliki anak, oleh karena itu keinginannya untuk memiliki anak sangat kuat. Dalam diri Susi ada keyakinan, anak perempuan ataupun anak laki-laki untuk anak pertama tidak menjadi persoalan, karena kalau sudah punya anak satu biasanya akan mudah untuk hamil anak yang kedua. Oleh karena itu usaha yang dia lakukan adalah sekuat tenaga untuk mendapatkan anak dengan cara berobat kesana kemari dan belum berhasil, dan terakhir setelah berobat kepada Nita ia berhasil memiliki anak perempuan. Baginya itu telah menandakan garis keturunan ia tidak punah.

Dari uraian latar belakang lima orang perempuan di atas dalam usahanya mendapatkan keturunan, maka ystem sekali kehadiran anak perempuan dalam sebuah keluarga bagi masyarakat Minangkabau memang sangat berpengaruh langsung bagi keberlanjutan anak keturunannya. Namun begitu bagi mereka juga sangat penting akan kehadiran anak laki-laki. Bagi empat orang (selain Susi) merasakan bahwa anak laki-laki yang akan jadi mamak rumah sudah mereka miliki. Tetapi induak bako atau induak bareh tidak ada jika memang mamak rumah tersebut tidak memiliki saudara perempuan.

Kehadiran anak laki-laki dalam rumah tangga masyarakat Minangkabau sangat memiliki arti karena laki-laki adalah sebagai pemimpin.Oleh karena beratnya peran sebagai pemimpin, maka sejak dini anak laki-laki dibekali bagaimana menjadi pemimpin kelak dia dewasa.Peran laki-laki dewasa dalam kehidupan masyarakat Minangkabau terutama sebagai mamak. ${ }^{5}$ Pengertian mamak yakni saudara laki-laki ibu.Sedangkan kemenakan terbagi dua kemenakan laki-laki dan kemenakan perempuan.Kemenakan laki-laki dibekali oleh mamak tentang persiapan untuk pusako batolong. Navis (1984:223) mengungkapkan maksud peran ini yakni sebagai penunjang dan pengembangan sumber-sumber kehidupan sanak saudaranya, terutama sanak saudara perempuannya yang akan melanjutkan turunan mereka. Terhadap kemenakan perempuan maka mamak membekali persiapan untuk menyambut warih bajawek dan persiapan melanjutkan keturunan. ${ }^{6} \mathrm{Jika}$ tidak memiliki anak laki-laki maka kesempatan memimpin tidak dimiliki karena itu semua adalah hak dari laki-laki.Sifat laki-laki secara kodrati adalah sebagai pemimpin, pengayom keluarga dan pencari nafkah utama.Itulah mengapa jika memiliki anak berjenis kelamin perempuan dan laki-laki dianggap telah sempurna dan seimbang.

\footnotetext{
${ }^{5}$ Mamak adalah peran dari laki-laki minangkabau. Yahya Samin dkk membagi fungsi dan klasifikasi mamak menjadi tiga jenis, yakni mamak rumah, mamak kaum dan mamak suku. Mamak rumah adalah saudara sekandung laki-laki ibu atau garis ibu "serumah gadang" yang terpilih menjadi wakil pembimbing anggota garis ibu yang terdekat. Istilah lain untuk mamak rumah adalah tungganai. Mamak kaum adalah seorang yang dipilih diantara beberapa mamak rumah yang terikat dalam hubungan darah yang disebut kaum.Pemilihan mamak kaum harus memenuhi suatu kriteria dari mamak-mamak rumah yang ada.Salah satunya adalah memiliki "budi yangdalam, bicara yang haluih" artinya orang yang berbudi pekerti, sopan santun, ramah tamah dan redah hati yang menjadi teladan bagi anak kemenakannya.Mamak suku yakni pimpinan suku.Lihat juga AA Navis (1984:119-148) yang menjelaskan lebih rinci mamak dalam judul besarnya Penghulu.

${ }^{6}$ AA. Navis (1984:223), pemahaman warih bajawek adalah pemahaman nilai-nilai lingkungan sosial yang menempatkan perempuan sebagai pusek jalo pumpunan ikan. Yang artinya mereka adalah titik pusat lingkungan masyarakatnya di rumah dengan peran sebagai nenek dan ibu yang akan mengasuh anak cucunya dan sebagai istri yang menjadi tali penghubung dengan lingkungan masyarakat lain.
} 
Oleh karena itu banyak usaha yang dilakukan oleh suatu keluarga masyarakat Minangkabau dalam mencapai keseimbangan dalam keluarga tersebut.Hal yang dilakukan adalah dengan berupaya sepenuh hati untuk melakukan berbagai hal dalam mencapai keinginannya mendapatkan anak laki-laki atau anak perempuan yang sangat didambakan.Meskipun harus melakukan suatu hal yang dianggap mitos yakni suatu hal yang dianggap oleh sebagian masyarakat belum tentu sepenuhnya benar.

Mitos oleh sebagian masyarakat selalu dianggap sebagai berita kebohongan.Kita tahu bahwa mitos adalah salah satu dari bentuk cerita prosa selain legenda dan dongeng. ${ }^{7}$ Mitos dilahirkan dari bahasa yang diucapkan menggambarkan suatu hal yang dilakukan oleh masyarakat. Adapun mitos yang dikenal juga dengan istilah mite menurut Shaw (dalam Sutarto,1997:12) memiliki beberapa pengertian yakni :1)cerita tradisional atau legenda biasanya tentang manusia yang memiliki kelebihna (superhuman)dan berkaitan dengan peristwa-peristiwa yang tidak bisa dijelaskan dengan akal; 2)suatu kepercayaan yang tidak bisa dibuktikan tetapi diterima kebenarannya begitu saja; 3) gagasan atau cerita buatan. Mite ini lebih cenderung kepada perasaan daripada nalar yang terjadi pada zaman dahulu ketika keterangan rasional tidak ada dan mungkin tidak dikehendaki. Sedangkan menurut Abraham (dalam Sutarto,1997:12).Mitos berarti cerita, yang dalam pengertian modern mite dalam mitologi merupakan suatu system cerita turun temurun yang pada suatu ketika dipercaya sebagai suatu yang benar-benar terjadi oleh suatu kelompok budaya tertentu, dan yang berfungsi untuk menjelaskan (berkenaan dengan maksud dan tindakan mahluk adikodrati ) mengapa dunia terjadi seperti ini dan bagaimana sesuatu terjadi, dan untuk menetapkan alasan atas adat - istiadat dan peribadatan serta sanksi-sanksi atas kaidah-kaidah yang digunakan sebagai tuntunan hidup.

Mitos sebagai bagian dari folklore atau cerita prosa yang menurut Bascom (dalam Sutarto,1997:19) berfungsi, yakni 1) sebagai ystem proyeksi, yakni cermin angan-angan suatu kolektif, 2) sebagai sarana pengesahan pranata-pranata dan lembaga-lembaga kebudayaan, 3) sebagai sarana pendidikan dan 4) sebagai sarana pemaksa dan pengawas agar norma-norma masyarakat akan selalu dipatuhi oleh kolektifnya.

\section{Mitos-mitos tanda-tanda yang diperlihatkan oleh ibu hamil terkait jenis kelamin janin dalam kandungan}

\footnotetext{
${ }^{7}$ Legenda cerita prosa rakyat yang dianggap oleh yag empunya cerita sebagai suatu yang benar-benar terjadi. Legenda memiliki beberapa maca.Jan Harold Brunvand menggolongkan legenda menjadi empat kelompok, yaitu legenda keagamaan (religious legends) legenda alam gaib (supernatural legends), legenda perseorangan (personal legends), dan legenda setempat (local legends).Dongeng dikenal juga dengan sebutan cerita rakyat.Definisi cerita rakyat yakni mengisahkan tentang suatu kejadian di suatu tempat atau asal muasal suatu tempat.Tokoh-tokoh yang dimunculkan dalam cerita rakyat umumnya diwujudkan dalam bentuk binatang, manusia maupun dewa. https://lianurbaiti.wordpress.com/2013/03/30/pengertian-dan-perbedaan-mitos-legenda-dan-cerita-rakyat/ diakses tanggal 1 Februari 2016.
} 


\begin{tabular}{|l|l|l|l|}
\hline No & Dilihat berdasarkan & Jenis Kelamin Laki-Laki & $\begin{array}{l}\text { Jenis Kelamin } \\
\text { Perempuan }\end{array}$ \\
\hline 1. & Bentuk Perut & Terlihat runcing ke depan & $\begin{array}{l}\text { Terlihat melebar ke } \\
\text { samping }\end{array}$ \\
\hline 2. & Posisi perut & $\begin{array}{l}\text { Janin di perut condong ke } \\
\text { atas }\end{array}$ & $\begin{array}{l}\text { Janin di perut condong ke } \\
\text { bawah }\end{array}$ \\
\hline 3. & Kerajinan merawat diri & \\
\hline 4. & Kebiasaan posisi tidur ${ }^{9}$ & $\begin{array}{l}\text { Rajin merawat diri tetapi } \\
\text { bersih }\end{array}$ & $\begin{array}{l}\text { Malas merawat wajah } \\
\text { tetapi terkesan kusam }\end{array}$ \\
\hline 5. & Kerajinan & rajin dan aktif & $\begin{array}{l}\text { tidur dengan posisi ke } \\
\text { kanan }\end{array}$ \\
\hline 6. & Kebersihan wajah & $\begin{array}{l}\text { Terlihat bersih walau } \\
\text { tidak rajin menggunakan } \\
\text { kosmetik }\end{array}$ & $\begin{array}{l}\text { Terlihat kusam walaupun } \\
\text { telah berdandan secantik } \\
\text { mungkin }\end{array}$ \\
\hline 7. & Kebiasaan makan & $\begin{array}{l}\text { Lebih menyukai daging- } \\
\text { dagingan dan makanan } \\
\text { yang rasa asin dan gurih. }\end{array}$ & $\begin{array}{l}\text { Lebih menyukai sayur- } \\
\text { sayuran dan rasa makanan } \\
\text { yang manis. }\end{array}$ \\
\hline 8. & Areola & $\begin{array}{l}\text { Seputaran aerola } \\
\text { cenderung gelap }\end{array}$ & $\begin{array}{l}\text { Seputaran aerola berwarna } \\
\text { terang }\end{array}$ \\
\hline 9. & Gerakan janin & Gerakan janin aktif & Gerakan janin lambat \\
\hline 10. & Hobi beraktifitas ${ }^{10}$ & Aktif beraktifitas & Malas beraktifitas \\
\hline
\end{tabular}

\section{Mitos-mitos tanda-tanda yang diperlihatkan dari bayi yang telah lahir untuk adiknya kelak}

\begin{tabular}{|l|l|l|l|}
\hline No & \multicolumn{1}{|c|}{$\begin{array}{c}\text { Dilihat } \\
\text { berdasarkan }\end{array}$} & \multicolumn{1}{|c|}{$\begin{array}{c}\text { Jenis Kelamin } \\
\text { Laki-Laki }\end{array}$} & \multicolumn{1}{|c|}{$\begin{array}{c}\text { Jenis Kelamin } \\
\text { Perempuan }\end{array}$} \\
\hline 1. & Hidung & Keras & Lunak \\
\hline 2. & Rambut & Kasar & Halus \\
\hline 3. & Putting susu & Bulat & Berbelah \\
\hline 4. & Lipatan paha & Satu & Lebih dari satu \\
\hline 5. & Gigi pertama tumbuh & Gigi bawah & Gigi atas \\
\hline
\end{tabular}

\footnotetext{
${ }^{8}$ Bagi masyarakat Jawa, justru tanda-tanda ini terbalik. Jika sang ibu hamil malas sekali merawat diri baik dan terkesan kusam. Selain itu juga rasa malas menghinggapi dalam bekerja membereskan rumah atau pun kegiatan lainnya, maka ini ini menandakan anak yang dikandungnya berjenis kelamin laki-laki. Hal ini sangat dipercaya oleh masyarakat Jawa pada masa lalu dan dikenal dengan ilmu titen. admin December 14, 2014 Ciri Ciri Hamil Anak Laki-Laki diakses tanggal 12 Desember 2015

${ }^{9}$ Di kebanyakan masyarakat justru berlaku tanda sebaliknya. Jika mengandung anak laki-laki maka si ibu hamil condong tidur ke arah kanan, sedangkan jika mengandung anak perempuan condong tidur dengan posisi ke kiri.lihat http://hamil.co.id/pra-hamil/ciri-ciri-orang-hamil/ciri-ciri-hamil-anak-laki-laki diakses tanggal 12 Desember 2015

${ }^{10}$ Mitos yang berkembang justru terbalik, jika malas beraktifitas kemanapun maka ini dianggap sedang mengandung anak laki-laki, sedangkan jika rajin beratifitas maka sedang mengandung anak perempuan. Lihat http://hamil.co.id/pra-hamil/ciri-ciri-orang-hamil/ciri-ciri-hamil-anak-laki-laki dan admin December 14, 2014 Ciri Ciri Hamil Anak Laki-Lakidiakses tanggal 12 Desember 2015
} 


\section{Usaha yang harus dilakukan agar mendapatkan bayi dengan jenis kelamin tertentu}

Berbagai macam usaha yang dapat dilakukan demi bisa mendapatkan bayi dengan jenis kelamin tertentu.Usaha yang dilakukan oleh masyarakat Ampek Angkek dengan mendatangi tukang urut yang dikenal mampu dalam melakukan ini. Metode urut adalah salah satu cara yang dilakukan dalam melakukan pertolongan kepada yang membutuhkan. Sebenarnya yang dilakukan oleh tukang urut yang pertama kali adalah mengurut badan secara keseluruhan guna memperbaiki jalannya peredaran darah. Setelah itu barulah diberikan makanan atau ramuan yang digunakan pengobatan selanjutnya. Pengetahuan dan pengalaman antara tukang urut yang satu dengan yang lain memiliki perbedaan. Begitu pula cara dan media urutnya. Pernyataan tukang urut dengan kepandaiannya masing-masing seperti yang diungkapkan oleh Nita (48 tahun $)^{11}$ berikut ini:

Awak dulu nda punyo kapandaian bauruik do. Tapi dek suami awak pandai mauruik, awak diajaannyo dima titik-titik syaraf dan apo panyakiknyo.Dari keturunan awak sabanyo dari nenek awak dikenal dukun uruik pado maso dulu. Tapi awak nda tau kok bisa sajo awak capek manarimo kapandaian ko. Alhmdulillah banyak yang nda bisa punyo anak bataun-taun, tu datang kamari untuak bauruik.Alhmdulillah agak tigo kali bauruik langsung hamil.

Artinya:

Saya dulu tidak punya kepandaian mengurut. Tapi karena suami saya pandai mengurut, saya diajarkannya dimana titik-titik syaraf dan apa penyakitnya. Dari keturunan saya sebenarnya dari nenek saya dikenal sebagai dukun urut pada masa lalu.Tapi saya tidak tahu kenapa saya mudah saja dalam menerima pengetahuan untuk mengurut ini.Alhamdulillah, banyak yang sudah berkeluarga bertahun-tahun dan tidak memiliki anak, kemudian berurut pada saya langsung hamil.

Begitu juga dengan ungkapan $\mathrm{Bu} \mathrm{Hj} . \mathrm{Er}(62 \text { tahun })^{12}$ berikut ini:

Awak kapandaian mauruik ko yo sejak gadih. Memang lah ado katurunan awak. Awak Insya Allah untuak urang nan ba uruik ko cukuik sakali sajo. Nda ado awak suruah mauling do. Kalau niyo mauling awak suruah lewat tigo hari lu. Nda namuah awak manarimo do kalau alun tigo hari. Awak mauruik jo minyak uruik yang awak buek surang campua jo ramuanramuan. Jo itu sajo awak ma uruik urang. Kalau mauruik biaso ambo nda ado ditargetkan jo apo syaratnyo. Tapi kalau jatuah dek kecelakaan iyo ado syaratnyo. Iko gunonyo supayo capek cegaknyo.

\footnotetext{
${ }^{11}$ Nita berusia 48 tahun, tinggal di nagari Sungai Rotan Kecamatan Ampek Angkek.Sehari-hari bekerja sebagai ibu rumah tangga dan membantu suami ke sawah. Wawancara dilakukan 1 Desember 2015.

${ }^{12} \mathrm{Bu} \mathrm{Hj}$. Er berusia 62 tahun, tinggal di Jorong Bonjo Alam, nagari Ampang Gadang Kecamatan Ampek Angkek.Sehari-hari bekerja sebagai pemilik usaha konveksi pakaian sekolah.Wawancara dilakukan tanggal 18 Desember 2015.
} 
Artinya:

Saya kepandaian mengurut ini sejak gadis.Memang sudah ada dari keturunan saya.Saya Insya Allah untuk orang yang berurut cukup sekali saja.Tidak ada saya suruh mengulang urut kembali.Kalau ingin kembali mengulang maka bisanya kalau sudah lewat tiga hari.Tidak mau saya menerima kembali kalau belum cukup tiga hari.Saya mengurut dengan minyak urut yang saya buat sendiri dicampur dengan ramuan-ramuan. Dengan itu saja saya mengurut orang. Kalau mau urut yang biasa saya tidak ada ditargetkan dengan apa syaratnya. Tapi kalau jatuh karena kecelakaan iya ada syaratnya.Ini gunanya supaya cepat sembuhnya.

Dewi (40 tahun) ${ }^{13}$ juga merupakan dukun urut yang menggunakan metode urut untuk menolong orang yang membutuhkan bantuannya. Ia juga mengungkapkan akan kepandaiannya berikut ini:

Awak iyo pandai mauruik dek kapandaian turunan. Dari nenek nan pandai mauruik turun ka kami baduo, awak (Dewi) jo adiak bungsu awak (Osi). Kalau awak mauruik urang yo jo minyak. Sudah tu beko jo aia putiah setelah dibaco doa tu diminum. Kalau nan barubek kaparaluannyo untuak maminta anak laki-laki atau padusi, awak menerapkannyo dari makanan.

Artinya:

Saya memang pandai mengurut karena merupakan kepandaian turunan.Dari nenek yang pandai mengurut turun ke kami berdua, saya (Dewi) dengan adik bungsu saya bernama Osi.Saya mengurut dengan menggunakan minyak. Setelah itu minum air putih yang telah dibacakan doa sebelumnya. Kalau yang pergi berurut memeinta anak laki-laki atau perempuan, maka saya akan menerapkannya melalui makanan.

Sedangkan Tek Ma (68 tahun) ${ }^{14}$ cara yang dilakukannya hanyalah dengan mengurut badan saja. Tidak menggunakan ramuan-ramuan tertentu. Hal ini seperti yang diungkapkan berikut ini:

Awak manolong urang yo jo kapandaian uruik ko. Sia nan maraso sakik di badannyo, atau mambaok anak nan tajatuah atau alun juo pandai jalan, InsyaAllah bisa awak ubek jo uruik ko. Banyak juo nan niyo punyo anak tapi sulik mandapek annyo. Di awak yo kaduo-duonyo baiak suami jo istri diuruik. Bauruik harus diulang minimal tigo kali. Sudah tu awak nda do maagiah apoapo do, paliang suruah se manjago badan jan talampau dipaso. Awak mandoa semoga yo bisa capek isi. Awak samo-samo mandoa.

\footnotetext{
${ }^{13} \mathrm{Bu} \mathrm{Hj}$. Er berusia 62 tahun, tinggal di Jorong Bonjo Alam, nagari Ampang Gadang Kecamatan Ampek Angkek.Sehari-hari bekerja sebagai pemilik usaha konveksi pakaian sekolah.Wawancara dilakukan tanggal 18 Desember 2015.

${ }^{14}$ Dewi 40 tahun suku Simabua tinggal di nagari Pakaladang, Kecamatan Ampek Angkek, bekerja sebagai ibu rumah tangga yang memiliki kepandaian mengurut. Wawancara dilakukan 12 Januari 2015.
} 
Artinya:

Saya menolong orang dengan kepandaian berurut ini.Siapa yang merasa sakit di badannya, atau membawa anak yang terjauth atau belum pandai jalan Insya Allah bisa saya obati melalui jalan urut.Banyak juga yang ingin punya anak tapi sulit mendapatkannya.Kalau saya kedua-duanya baik suami dan istri di urut.Berurut harus diulang minimal tiga kali.Sudah itu saya tidak mengasih apa-apa, paling saya suruh saja menjaga badan jangan terlalu dipaksa.Saya berdoa semoga dia cepat hamil.Kita sama-sama berdoa.

Pengalaman mengikuti suatu kepercayaan dalam usaha mencapai keinginan mendapatkan anak dengan jenis kelamin tertentu banyak dilakukan. Seperti yang diutarakan oleh Leni (45 tahun) berikut ini yang pergi berurut kepada tukang urut bernama Nita:

Awak lah ado tigo anak laki-laki.Alah gadang-gadang. Nda lasuah lo kok nda ado anak padusi ko. Lah tabayang se dek awak baa bisuak tiko wak lah gaek anak-anak lah bi pai ka rumah bininyo. Awak bausao juo untuak dapek anak padusi. Tiko tu sabananyo awak niyo bauruik se karumah Nita tu. Tiko sadang antri manunggu giliran ba uruik, ado padusi nan lain nan manyabuik baso inyo niyo bana anak padusi. Makonyo inyo ka rumah Nita untuak ba uruik. Banyak yang lah berhasil sampai kini ko. Dek itu wak sato lo bauruik u dapek anak padusi. Alhmdulillah awak dapek anak padusi.

Artinya :

Saya telah punya anak laki-laki tiga orang.Sudah besar-besar.tetapi tidak menyenangkan rasanya kalau tidak punya anak perempuan.Sudah terbayang oleh saya nanti kalau kita telah tua anak-anak telah besar dan berkeluargapergi ke rumah istrinya.Saya berusaha juga untuk mendapatkan anak perempuan.Ketika itu sebenarnya saya hanya ingin berurut saja kerumah Nita itu. Sedang menunggu giliran berurut, ada perempuan menyebutkan kalau dia ingin punya anak perempuan.Makanya dia kerumah Nita ini.Banyak yang telah berhasil sampai sekarang.Karena itu saya ikut juga untuk berurut agar bisa mendapatkan anak perempuan.Alhamdulillah saya bisa dapatkan anak perempuan.

Kenyataan yang sama dengan yang diungkapkan oleh Lili (34 tahun) sudah memiliki anak pertama laki-laki. Tapi ia sangat ingin untuk bisa mendapatkan anak kedua berjenis kelamin perempuan. Maka yang ia lakukan adalah dengan pergi berurut kepada Dewi kemudian mengikuti segala saran yang dikatakan oleh tukang urut tersebut. Hal ini seperti yang diungkapkannya berikut ini:

Awak iyo lah punyo anak patamo nan laki-laki. Jadi awak niyo bana beko pas ka anak duo dapek anak padusi. Dek suami sabananyo nda masalah beko nan anak kaduo tu laki-laki atau padusi do. Dek suami awak katonyo samo sajonyo.Tapi awak iyo bana niyo anak padusi.Jadi dek kakak awak pandai mauruik, awak cubo sajo katoan ka kakak wak.Sudah tu awak diuruiknyo. 
Sudah diuruik awak jo suami awak disuruah mahantian makanan sagalo dagiang. Nan dimakan yo sayua sajo salamo ampek bulan.Alhamdulillah pas lahia yo dapek padusi.

Artinya :

Saya memang sudah punya anak pertama yang laki-laki.Jadi saya ingin sekali nanti pas anak kedua dapat yang perempuan. Oleh suami sebenarnya tidak masalah apakah nanti anak kedua laki-laki atau perempuan. Bagi suami saya katanya sama saja. Tapi saya benar-benar ingin punya anak perempuan.Jadi karena kakak saya yang pandai berurut, saya coba bilang pada kakak saya dan sudah itu saya diurut.Setelah diurut saya dan suami disuruh menghentikan makanan yang berbahan daging. Yang dimakan sayuran saja selama empat bulan.Alhamdulillah pas melahirkan saya dapat anak perempuan.

Pergi berurut ke tukang urut tidak hanya bagi yang berkeinginan mendapatkan anak perempuan atau anak laki laki saja.Tetapi dilakukan juga oleh pasangan suami istri yang sudah lama menjalani rumah tangga tetapi belum juga bisa mendapatkan keturunan.Hal ini banyak dilakukan dengan mendatangi Nita baik pasangan yang berasal dari daerah sekitar atau juga dari luar daerah Ampek Angkek, yakni Pekanbaru atau Jambi.Informasi ini biasanya didapat dari mulut ke mulut dari orang yang pernah berhasil.

Pengobatan melalui Nita dengan permasalahan lama berumah tangga tetapi belum mempunyai momongan dilakukan secara pasangan. Si Istri akan diurut oleh Nita, sedangkan si Suami akan diurut oleh suami Nita (Ajo minyak angek). Pengalaman ini seperti diungkapkan oleh informan bernama Susi (31 tahun) berikut ini :

Awalnyo awak kenal Nita tu dek ado urang kampuang nan manyabuik an baso ado nan bisa mauruik untuak bisa dapek anak. Awak lah limo tahun barumahtanggo tapi alun juo dapek anak.Alah kama-kama awak pai barubek, tapi alun juo dapek.Setelah wak tau dima alamat Nita tu, tu kami turuik. Nita tu manyabuik, kalau bauruik niyo punyo anak mako awak harus baduo jo suami awak bauruik. Awak di uruik jo Nita sedangkan suami awak diuruik jo suami Nita yang dikenal namonyo Ajo minyak angek.

Artinya:

Awalnya saya kenal Nita karena ada orang kampung (saudara sekampung Susi) yang menyebutkan bahwa ada yang bisa mengurut untuk bisa dapatkan anak. Saya telah lima tahun berumahtangga tetapi belum juga mendapat anak. Sudah kemana-mana saya pergi berobat tetapi belum juga dapat.Setelah saya tahu dimana alamat Nita kami pergi berurut.Nita menyebutkan kalau berurut ingin punya anak, maka harus berurutnya berdua dengan suami.Saya diurut oleh Nita, sedangkan suami diurut juga oleh suami Nita yang dikenal namanya Ajo minyak panas.

Ketiga informan di atas adalah informan yang berhasil mendapatkan keinginannya akan anak jenis kelamin yang didambakannya. Lalu berbeda dengan pengalaman ibu hamil yang mencoba pergi beruruik dan tidak berhasil mendapatkan keinginannya akan anak dengan jenis 
kelamin tertentu. Salah satunya adalah yang bernama informan Via (34 tahun) yang mencoba berurut ke tukang urut bernama Nita, berikut ini:

Awak yo lah punyo anak duo urang laki-laki.Niyo bana dapek anak padusi. Anak nan kaduo ko yolah jauah lo jaraknyo mah. Lah limo taun umuanyo. Minta tolong awak untuak dipelok an paranak an awak, ma tau tinggi atau paneh. Jadi tiko tu awak ba uruik jo minyak biaso punyo Nita tu dek karano badan panek-panek. Jadi agak saminggu lai awak disuruahnyo untuak datang baliak ka rumahnyo jo mambaok minyak untuk diangek an campua jo limau kambiang 3 buah. Tiko tu yo awak ka rumahnyo, sudah bauruik awak disuruahnyo mancari sipuik sawah agak sapalasti ketek tu di baok ka Nita untuak didoaan, baru sudah tu di masak, dan aianyo diminum, itu syaratnyo untuak dapek anak padusi. Tapi dek karano mancari sipuik sawah tu payah dan nda dapek juo salamo dua minggu bacari, ranggaek wak bali se sipuik danau. Wak baok ka Nita, tanyato sipuiknyo salah jadi nda paguno. Dek karano dipareso sejak diuruik patamo kali jo minyak biasao tu, tanyato awak lah isi. Jadi nda usah lai cari sipuik sawah tu lai. Disuaruahnyo awak untuak badoa semoga bisa dapek kandak awak tu. Tanyato pas lah laia, anak wak laki-laki liak. Tapi awak nda putuih aso do. Awak ka barubek lo bisuak ko kok lah gadang anak bungsu awak kini ko.

Artinya :

Saya sudah punya dua orang laki-laki.Ingin sekali dapat anak perempuan.Anak yang kedua ini jaraknya jauh dengan yang telah lahir sekarang. Anak kedua telah lima tahun umurnya. Saya minta tolong untuk diperbaiki letak peranakan saya mana tahu tinggi atau panas.Jadi ketika itu saya berurut memakai minyak urut biasa yang digunakan oleh Nita kalau badan terasa lelah. Katanya seminggu lagi harus mengulang urut dengan membawa minyak untuk dipanaskan dicampur dengan membawa limau kambing 3 buah. Ketika itu saya ke rumahnya, setelah berurut saya disuruh mencari Siput sawah dengan jumlah satu kantong plastik dan dibacakan doa oleh Nita, setelah itu dimasak dan diminum air rebusannya. Ini adalah syarat untuk bisa mendapatkan anak perempuan.Tapi karena untuk mencari Siput sawah itu sulit telah dua minggu dicari tetapi tidak dapat. Yang dapat adalah Siput danau.Setelah itu dibawa ke Nita, tetapi karena Siput yang dimaksud berbeda jadi tidak digunakan. Karena ternyata ketika urut pertama kali sebelum menggunakan minyak panas ternyata telah hamil.Jadi tidak usah cari Siput sawah lagi.Jadi disuruhnya saya untuk berdoa semoga bisa dapat keinginan anak perempun. Ternyata anak yang lahir laki-laki.Tetapi saya tidak putus asa. Saya akan berobat lagi kalau nanti anak yang kecil sudah besar.

\section{Persepsi masyarakat Minangkabau terhadap mitos tanda-tanda yang diperlihatkan dan usaha yang dilakukan oleh ibu hamil tersebut}

Keberadaan tanda-tanda dan usaha yang tampak dalam keseharian ibu hamil dalam menjalankan aktivitasnya memang tidak semuanya benar berhubungan dengan jenis kelamin anak. Bagi sebagian masyarakat yang mempercayainya, maka mitos dari tanda-tanda itu akan 
memberikan hubungan yang sangat erat. Berbeda dengan sebagian masyarakat yang tidak mempercayai mitos tersebut.Mereka hanya berujar bahwa tanda tersebut hanya kebetulan saja dengan jenis kelamin anak yang dilahirkan. Usaha yang dilakukan tidak ada hubungannya dengan jenis kelamin, seperti yang dilakukan oleh Via. Relevansi sipuik sawah dengan anak jenis kelamin perempuan tidak ada.Tambah lagi dengan keadaan sawah yang saat ini sudah banyak berkurang, dan semenjak ada pemakaian pupuk pestisida keberadaan siput sawah sudah jarang. Tentunya berkurangnya siput sawah tidak relatifsama dengan berkurangnya anak berjenis kelamin perempuan lahir ke bumi.

Via (35 tahun) sebagai seorang ibu yang gagal mendapatkan anak dengan jenis kelamin perempuan yang sangat didambakannya, mengungkapkan pandangannya seperti berikut ini:

Sabanyo awak yo ragu bana tentang kemampuan urang baiak dukun ataupun urang biasao untuak bisa manakok jenis kelamin yang akan lahia di ateh dunia ko. Awak yakinnyo baso jenis kelamin anak ko lah ditantuan di Allah sabalun manusia ko ado di bumi. Makonyo awak nda gigiah bana untuak mancari sipuik tu dek karano memang sangaik payah pulo mancarinyo. Awak ragunyo dek karano tiko bauruik jo minyak angek, kironyo awak lah manganduang 4 minggu. Kalau tukang uruik nan tau, pasti nyo tau kalau awak sadang ba isi. Kironyo Nita tu nda tahu do. Bisuak awak cubo lo jo nan lain, nan bisa masuak ka aka awak.

Artinya :

Sebenarnya saya ragu tentang kemampuan orang baik itu dukun ataupun orang biasa yang bisa menebak jenis kelamin yang akan lahir di dunia ini.Saya yakin kalau jenis kelamin anak ini telah ditentukan Allah sebelum manusia ada di bumi. Makanya saya tidak terlalu gigih untuk mencari Siput sawah karena memang susah untuk mencarinya. Saya ragunya karena ketika berurut dengan minyak panas, ternyata sudah hamil empat minggu.Kalau tukang urut yang tahu, pasti dia tahu kalau saya sedang hamil.Kiranya Nita tidak tahu. Besok saya coba yang lain, yang bisa masuk akal saya.

Metra (30 tahun) ${ }^{5}$ salah seorang ibu muda yang telah memiliki dua anak laki-laki. Dahulu ia sangat menginginkan kehadiran anak perempuan sebagai anak keduanya. Kemudian ia pergi berurut ke salah satu tukang urut yang bernama Mak Ipan (73 tahun). Setelah berurut kemudian si Metra disuruh untuk mencuri telur ayam kampung dari orang yang memiiki anak perempuan banyak tetapi ia peternak ayam. Setelah berhasil mencuri kemudian dimakan telur sebelumnya dibacakan doa oleh Mak Ipan. Ternyata setelah usia kandungannya cukup dan tiba waktunya untuk melahirkan, yang lahir adalah bayi laki-laki. Bukan bayi perempuan seperti yang didambakannya selama ini.

Kegagalan mencapai keinginan memiliki anak dengan jenis kelamin tertentu sebenarnya tidak hanya terjadi di Ampek Angkek saja, tetapi di banyak daerah lainnya juga seperti itu.Betapapun mitos tanda-tanda menunjukkan kepada ibu hamil akan melahirkan anak lakilaki, ternyata tidak semuanya benar. Hal ini seperti yang diutarakan Ida (51 tahun ) berikut ini berdasarkan pengalaman melahirkan anak laki-laki sebanyak lima orang. 
Ambo yo bana ingin punyo anak padusi. Tiko patamo kali manganduang awak cuek sajo kok apo nan laia. Ruponyo nan laia anak laki-laki. Manganduang kaduo awak cubo lo nan kato-kato urang caro mandapek anak padusi. Kok lalok yo mereng ka kida.Kok makan yo pabanyak sayua kurangi dagiang. Tapi jiwa ambo yo nda suko do yang mantiak-mantiak taka urang padusi. Awak tetap juo cuek urangnyo.Kato urang kok niyo baranak padusi yo cubo lemah lembut mangecek ka suami.Pabanyak jiwa seni kaibuan. Baa lo ambo ka bisa mode itu. Ambo tu yo cuek sajo urangnyo. Mode itu taruih sampai terakhir ambo malahian anak nan ka limo, tatap juo nan laia laki-laki. Mungkin lah sudah di Allah awak yonda dipicayo baranak padusi doh.

Artinya :

Saya benar-benar ingin punya anak perempuan. Ketika pertama kali mengandung saya cuek sajaapa yang lahir (apakah anak laki-laki atau anak perempuan, pen). Rupanya yang lahir anak laki-laki. Mengandung anak ke dua saya coba apa yang kata-kata orang cara mendapat anak perempuan. Kalau tidur posisi miring ke kiri.Kalau makan ya diperbanyak sayur dikurangi daging. Tapi jiwa saya tidak suka yang centil-centil seperti anak perempuan.Saya tetap saja cuek orangnya.Kata orang kalau mau punya anak perempuan maka dicoba untuk lemah lembut berbicara pada suami.Perbanyak jiwa seni keibuan.Bagaimana saya bisa seperti itu.Saya ini orangnya cuek. Seperti itu lah keadaannya sampai saya melahirkan anak ke lima tetap saja yang lahir laki-laki. Mungkin sudah suratan di Allah kalau saya tidak dipercaya untuk memiliki anak perempuan.

\section{PENUTUP}

Masih banyaknya masyarakat Ampek Angkek yang mempercayai pengobatan melalui urut ini, maka keberadaan tukang urut masih diperlukan.Hal ini dikarenakan kepercayaan masyarakat mengenai kepandaian seseorang dalam pengobatan dengan metode urut tidak hanya berkenaan dengan usaha mendapatkan anak saja.Melainkan untuk pengobatan berbagai penyakit yang banyak diderita oleh masyarakat baik lahir maupun bathin.Justru kenyataan di lapangan, pengobatan dengan metode urut banyak juga dilakukan oleh orang yang berlatar belakang kesehatan.Baik itu dokter, bidan atau perawat.

Tanda-tanda dan berbagai usaha yang dilakukan untuk mendapatkan anak dengan jenis kelamin tertentu masih banyak dilakukan oleh masyarakat. Hal ini dikarenakan bagi sebagian orang masih terbukti berhasil.Bagi ibu yang belum berhasil mendapatkan keinginannya tetap saja terus berusaha untuk kehamilan berikutnya selagi masih memungkinkan baginya dalam menjalankan kehamilan dengan aman dan selamat.Hal ini sangat terkait dengan latar belakang kehidupan masyarakat Minangkabau yang menganut system garis keturunan matrilineal.Kehadiran anak laki-laki ataupun perempuan memiliki arti yang sangat penting. Anak perempuan sebagai pelanjut keturunan atau warih bajawek sedangkan laki-laki berperan sebagai pusako batolong yang sangat terkait dengan keberadaan kaum perempuan sebagai pelanjut keturunan. 


\section{DAFTAR PUSTAKA}

Admin, 2014. Ciri-ciri Hamil Anak Laki-Laki, http://cirihamil.com/ciri-ciri-hamil-anak-laki-laki/ diakses tanggal 27 Januari 2016 (online)

Admin. 2015. Pra Hamil: Ciri-ciri hamil anak laki-laki, http://hamil.co.id/pra-hamil/ciri-ciri-oranghamil/ciri-ciri-hamil-anak-laki-laki diakses tanggal 12 Desember 2015(online)

Afrizal, 2008.Pengantar Metode Penelitian Kualitatif : dari Pengertian sampai Penulisan Laporan.Padang : Laboratorium Sosiologi FISIP Unand.

Angga, 2014.Ma'Blien: Dukun Beranak Di Aceh. Banda Aceh : Balai Pelestarian Nilai Budaya Banda Aceh.

Barthes, Roland, Alih Bahasa Christian Ly, 2003. Mitologi.Padang : Dian Aksara Press

Koentjaraningrat (1998).Pengantar Antropologi II: Pokok-Pokok Etnografi. Jakarta: PT. Rineka Cipta.

Mansur, M.D, dkk. 1970. Sedjarah Minangkabau. Bukittinggi: Bhratara

Peursen, Van, C.A. 2013, Strategi Kebudayaan.Yogyakarta : Kanisius.

Pujiraharjo, Sidarta dan Rudito, Bambang. 1998. Folklore Desa Balai Janggo dan Desa Kampung Tangah, Nagari Pagaruyung Kecamatan Tanjung Emas Kabupaten Tanah Datar Sumatera Barat dalam Jurnal Antropologi Tahun I. No. 1. Juli-Desember 1998.Padang : Laboratorium Antropologi FISIP Universitas Andalas.

Refisrul, 2011.Keluarga Minangkabau Tanpa Anak Perempuan: Problematika dan Implikasi Sosial. Padang : BPSNT Padang Press

Samin, Yahya, dkk. 1996. Peranan Mamak Terhadap Kemenakan dalam Kebudayaan Minangkabau Masa Kini.Padang : Bagian Proyek Pengkajian dan Pembinaan Nilai-Nilai Budaya Sumatera Barat.

Straus, Claude Levi, 1997. Mitos, Dukun, dan Sihir. Penerjemah Drs. Agus Cremers, SVD dan Drs. De Santo Johanes. Yogyakarta : Kanisius.

Sutarto, 1997.Legenda Kasada dan Karo Orang Tengger, Lumajang.Depok: Fakultas Sastra Universitas Indonesia.

Tim Penyusun Kamus Pembinaan dan Pengembangan Bahasa, 1997.Kamus Umum Besar Bahasa Indonesia, Jakarta : Balai Pustaka.

Utari, Ida. 2015. Study of Developing the Myths of Pregnancy, https://publikasiilmiah.ums.ac.id/ bitstream/handle/11617/5178/7.Ida\%20Utari.pdf?sequence=1diakses Akses 27 januari 2016 (online)

Wahyuningsih, 1992.Pengobatan Tradisional Pada Masyarakat Daerah Sumatera Barat.Jakarta : Departemen Pendidikan dan Kebudayaan, Proyek Penelitian Pengkajian dan Pembinaan Nilai-Nilai Budaya

Yin, Robert K. 2011. Studi Kasus Desain dan Metode.Jakarta : Raja Grafindo Persada

Yunis, M. 2010. Dekonstruksi Mitos Kehamilan (Tindak Tutur, Semiotik, e 135, dan Filsafat Kehendak). Padang : Minangkabau Press 